UDC 539.3

\title{
CREATION OF MATHEMATICAL MODEL OF PLATFORM- VIBRATOR WITH SHOCK, DESIGNED FOR CONCRETE PRODUCTS COMPACTION AND MOLDING
}

\author{
V.A. Bazhenov, \\ Doctor of Technical Science \\ O.S. Pogorelova, \\ Candidate of Science (Engineering) \\ T.G. Postnikova \\ Candidate of Science (Engineering) \\ Kyiv National University of Construction and Architecture \\ 31, Povitroflotsky ave., Kyiv, Ukraine, 03680
}

DOI: $10.32347 / 2410-2547.2020 .104 .103-116$

Platform-vibrators are the main molding equipment in the production of precast concrete elements. Shock-vibration technology for the precast concrete production on low-frequency resonant platform-vibrators significantly improves the quality of the products front surfaces and the degree of their factory readiness. This technology is used to produce large elements.

We describe the creation of a mathematical model for platform-vibrator that uses shock to produce asymmetric oscillations. The values of the upper and lower accelerations of the mold with concrete have different values with shock-vibration technology.

The created mathematical model corresponds to the two-body 2-DOF vibro-impact system. It is strongly nonlinear non-smooth discontinuous system. It has some peculiar properties, namely: the upper body with very large mass breaks away from the lower body during vibrational motion; both bodies move separately; the upper body falls down onto the soft constraint; the impact that occurs is soft one due to the softness and flexibility of the constraint. The soft impact simulation requires special discussion. In this paper, we simulate a soft impact by a nonlinear contact force in accordance with the Hertz quasistatic contact law.

The numerical parameters for this system were chosen in such a way that: firstly they provide the fulfillment of requirements for real machine, and secondly they allow analyzing its dynamic behavior by nonlinear dynamics tools. The created model is well enough to fulfill a number of requirements, namely: $T$-periodic steady-state movement after passing the transient process; the appropriate value of mold oscillations amplitude; the satisfactory value of the asymmetry coefficient that is the ratio of lower acceleration to the upper acceleration. We believe that the created model meets all the necessary requirements.

Keywords: platform-vibrator, shock, vibro-impact, mold with concrete, upper and lower accelerations.

\section{Introduction}

Molding processes are one of the most important in the manufacture of reinforced concrete structures. Now vibration and shock-vibration technologies for concrete mixtures compaction and concrete products molding have the greatest distribution in the construction industry. This priority is likely to continue in the future. Therefore, the issues of optimizing vibration modes, proper selection of vibration equipment do not lose their significance [1].

(C) Bazhenov V.A., Pogorelova O.S., Postnikova T.G. 
At the end of the last century 60s extensive technological researches began to optimize the molding modes. Gradually, it became clear that low-frequency compaction modes have undoubted advantages: they allow obtaining highdensity concrete with a shorter compaction time. The asymmetric modes turned out to be very effective. The values of the upper and lower accelerations have different values under these regimes. Such modes are called shock-vibrational, and technology - shock-vibration. For their implementation, low-frequency resonant platform-vibrators were created. In recent years, shock-vibration modes have been widely used in various fields of technology.

Shock-vibration technology for the precast concrete production on lowfrequency resonant vibratory platforms significantly improves the quality of the products front surfaces and their factory readiness degree. Platform-vibrators are the main molding equipment in the production of precast concrete elements [2]. Such equipment are produced in several factories in Russia.

Studies have confirmed that low-frequency resonant vibration platforms and shock-vibration technology allow to obtain higher quality products in comparison with other vibration platforms.

A complex process of concrete mixture particles interaction with each other occurs under vibration influence. Many aspects of this process are not well understood.

The proposed models and the corresponding equations of the concrete mixture state, the criteria for the compaction effectiveness and the front surfaces quality remain debatable [3].

Many experiments have been conducted to study various aspects of the concrete compaction process.

The magnitude of the working body acceleration $w$ was taken as one of the most important factors affecting the compaction process. It determines the values of dynamics strengths in machine elements to a large extent. So, it links technology process characteristics and strength machine characteristics.

If the working body makes asymmetric oscillations, it is advisable to take into account the upper acceleration $w_{U}$ and the lower one $w_{L}$. Upper acceleration is the acceleration of the mold with concrete at its highest position, and lower acceleration is the acceleration of the mold in its lowest position [4].

Studies were carried out at various values of the working body oscillations frequency.

Experiments with concrete mixtures of other compositions have confirmed that the concrete macrostructure formation is faster and better at a lower frequency and increased amplitude of the working body vibrations.

The goal of the paper is to create a mathematical model of platform-vibrator with shock and to select its numerical parameters so that:

a) the model maximally corresponded to the requirements for a real machine;

b) the model made it possible to analyze its dynamic behavior using nonlinear dynamics methods. 


\section{Two body platform-vibrator with shock}

When developing resonant vibratory machines, designers have to take into account a large number of various requirements presented by modern production to new equipment. The realization of close to optimal operating mode is one of the most significant and fundamental. Its successful implementation is largely determined by the successful choice of the principle vibro-machine scheme and, as a consequence of this, its design scheme.

The specifics of many dynamic schemes was carefully analyzed in the work on resonant vibratory machines for compaction of concrete mixtures. It turned out that the conditions for optimal functioning can be satisfied by relatively simple two-mass systems. The creation of vibroforming machines with the number of main moving masses more than two is impractical, since this leads to an unjustified complication of the machines design.

The two-mass platform-vibrator with shock is one of the successful solutions for vibration equipment that implements shock-vibration technology for concrete mixtures compaction and reinforced products molding [5]. Its principled scheme is shown in Fig.1.

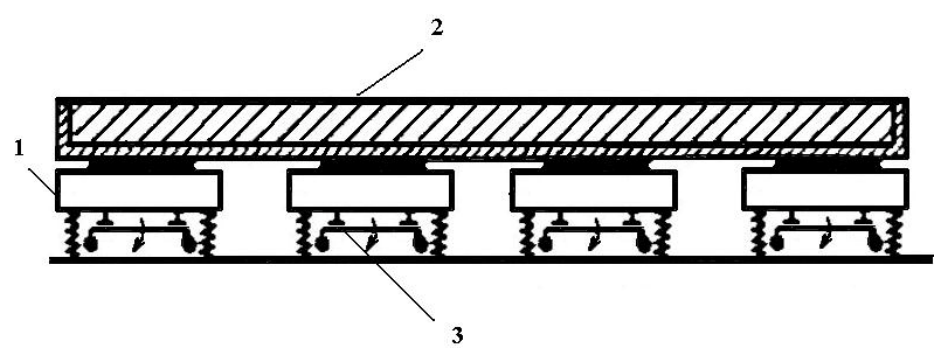

Fig.1 Principled scheme of platform-vibrator:

1 - working body; 2 - mold with concrete; 3 - vibration exciter.

The shock-vibration platform of block type consists of separate blocks on which rubber plates limiters are fixed. The mold with concrete mix is installed on the stops without fastening. With oscillations, the mold breaks away from the limiters and then falls on them. The mold collides with the limiters with oncoming movement. Two general vibration exciters are installed on each block.

One of the most important factors affecting the compaction process is the value of the working body acceleration $w$. More precisely, the ratio of the lower acceleration $w_{L}$ to the upper $w_{U}$ is important.

This can be explained as follows. With vertical oscillations, separation of the mixture from the pallet is possible only when the inertial forces applied to the particles of the concrete mixture act upward. The mixture is pressed to the mold pallet when inertial forces on the particles act downward [4].

The process of concrete mixture compaction is made more intensive due to such asymmetric vertical form vibrations. Accelerations $w_{U}$ that tear off 
mixture from the form pallet become smaller, and the pressing accelerations $w_{L}$ become larger with such oscillations. These asymmetric vibrations can be obtained precisely in shock-vibration compaction machines [4].

It is necessary to take into account the influence of concrete mix on the machine dynamics when calculating vibration compaction machines. So, it is necessary to consider the compacting machine and concrete mixture as a single dynamic system. But the concrete mixture is a complex viscoplastic medium. It has some elastic properties in the presence of air (especially in the initial period of compaction). All this makes it extremely difficult to solve a single dynamic system "compacting machine - concrete mixture". The question about the nature of the machine interaction with the medium being processed remains the most complex and least investigated. However, the influence of the concrete mixture can be taken into account as an attached mass and some additional damping when practical calculating and, in particular, determining the amplitude-frequency responses of a vibratory machine [3].

The forces of resistance, despite their relative smallness, play a significant role in resonant and close to them oscillation modes. These forces are "used" by the system to compensate the energy coming from the external load. Therefore, it is necessary to take into account the resistance force in the resonance zone. They have not significant effect on the result outside this zone.

The attenuation coefficients are calculated from experimental data. One can assume that the dissipation energy is relatively small and significantly affects only on the resonating harmonic. Such an assumption may simplify the problem. However, accounting for energy dissipation in elastic elements is very important when studying the vibrations of an elastic system in the resonance region. Internal friction is determined by a number of factors. Their influence is difficult to take into account directly. There are many hypotheses to describe dissipative forces. The most widely used is the Kelvin-Voigt hypothesis. It is often called the viscous friction hypothesis. It suggests that dissipative forces are proportional to the strain rate of elastic bonds [6].

The parameters of the exciting force and of the system (the mass of the frame with the mold and concrete mixture, the stiffness coefficients of the vibration limiters, etc.) are selected so that the machine operating mode is close to resonant. That is, so that the natural frequency of the system is close to the frequency of the exciting force.

Resonant vibration platforms have wide possibilities for regulating the modes of working body oscillations. One can change both the amplitude and frequency, and the very law of working body oscillations in the machine tuning process.

The presence of two main moving masses allows us to solve two problems: to provide the necessary law of working body movement and to create an effective vibration isolation system. This can be achieved by appropriate selection of the elastic bonds characteristics. 
One of the main disadvantages of resonance modes is associated with high system sensitivity to a change in its parameters, which is due to its strong nonlinearity. One can observe such sensitivity in real vibratory machines due to changes in the technological load mass, the characteristics of shock dampers and so on.

The calculation schemes for determining the amplitude-frequency responses of resonant vibration machines are based on assumptions usual to most applied problems of the oscillations theory. The main moving masses are assumed to be absolutely rigid. The masses of elastic bonds are not taken into account due to their relative smallness. Conditions guaranteeing single-axis motion are also fulfilled.

Such assumptions turn out to be quite acceptable and do not introduce significant errors in the final results of resonant vibratory machines calculating.

\section{The mathematical model of platform-vibrator with shock}

The calculation scheme of platform-vibrator is shown in Fig.2. Exciting force $F(t)=P \cos \left(\omega t+\varphi_{0}\right)$, its period is $T=2 \pi / \omega$.

Platform shock table with mass $m_{1}$ is attached to the base by linear vibration isolating spring of stiffness $k_{1}$ and a linear dashpot with damping factor $c_{1}$. Exciting external periodic force $F(t)$ is generated by electric motors mounted under the table. Elastic

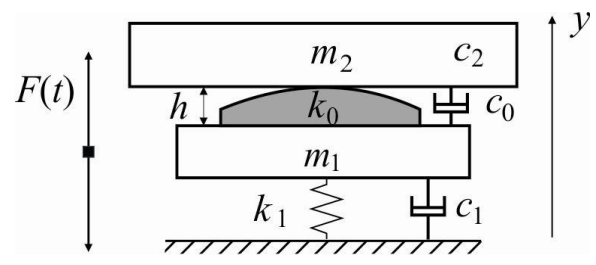

Fig.2 rubber gasket with thickness $h$ and stiffness $k_{0}$ is attached to the table. A linear dashpot with damping factor $c_{0}$ is placed between the table and the mold. Mold with concrete with mass $m_{2}$ is placed on the gasket but is not fixed both to the gasket and to the table. So it can tear herself away from the gasket and bounce. The machine starts their movement when the electric motors begin their work. First, the table and the mold move vertically together. Then the mold comes off from the gasket. The table and the mold are moving separately until the mold falls down onto the rubber gasket. Impact occurs. The bodies move together again until the mold comes off the gasket and so on.

This shock-and-vibration machine is two-body 2-DOF vibro-impact system. The model has the following features: a large mass of the falling body - mold with concrete; softness, flexibility of one contacting surface - rubber gasket; separation of the one body (mold) from another (table with gasket) and their separate motion. One can consider the impact between mold and table with gasket as soft one because of the softness, flexibility of the rubber gasket.

Thus, we consider three states of the platform vibrator: the initial joint movement of both bodies, separate movement in case of loss of contact between 
them, and joint movement during the impact due to the form falling onto the gasket.

The forces acting on the bodies are as follows.

The elastic force in spring is

$$
\left.F_{k 1}=k_{1} \Delta l_{1}=k_{1}\left(y_{1}-\lambda_{s t}\right)\right] .
$$

The elastic force in rubber gasket is

$$
F_{k 0}=k_{0} \Delta l_{0}=k_{0}\left[h-\left(y_{2}-y_{1}\right)\right] \text {. }
$$

The origin of coordinate $y$ is chosen in the table centre in the state of static equilibrium. The static deformation of spring is

$$
\lambda_{s t}=\frac{\left(m_{1}+m_{2}\right) g}{k_{1}} .
$$

The damping forces are taken to be proportional to the first degree of velocity:

$$
F_{\text {damp } 1}=c_{1} \dot{y}_{1}, F_{\text {damp } 0}=c_{0} \dot{y}_{1} .
$$

The influence of the concrete mixture can be taken into account as some additional damping $c_{2} \dot{y}_{2}$.

Then the primary joint movement of the table and the form until the first separation is described by the equations:

$$
\begin{aligned}
& m_{1} \ddot{y}_{1}=-m_{1} g-F_{k 1}-F_{d a m p 1}-F_{k 0}+F_{\text {damp } 0}+F(t), \\
& m_{2} \ddot{y}_{2}=-m_{2} g-c_{2} \dot{y}_{2}+F_{k 0}-F_{\text {damp } 0} .
\end{aligned}
$$

We introduce the standard notation:

$$
\frac{k_{1}}{m_{1}}=\omega_{1}^{2}, \frac{k_{0}}{m_{2}}=\omega_{2}^{2}, \frac{c_{0}}{m_{2}}=2 \xi_{0} \omega_{2}, \frac{c_{1}}{m_{1}}=2 \xi_{1} \omega_{1}, \frac{c_{2}}{m_{2}}=2 \xi_{2} \omega_{2}, \frac{m_{2}}{m_{1}}=\chi .
$$

The equations of primary joint movement will be written as follows;

$$
\begin{aligned}
& \ddot{y}_{1}=g \chi-\omega_{1}^{2} y_{1}-\omega_{2}^{2} \chi\left[h-\left(y_{2}-y_{1}\right)\right]-2 \dot{y}_{1}\left(\xi_{1} \omega_{1}-\xi_{0} \omega_{2} \chi\right)+\frac{1}{m_{1}} F(t), \\
& \ddot{y}_{2}=-g+\omega_{2}^{2}\left[h-\left(y_{2}-y_{1}\right)\right]-2 \omega_{2}\left(\xi_{2} \dot{y}_{2}+\xi_{0} \dot{y}_{1}\right) .
\end{aligned}
$$

The initial conditions are:

$$
\text { at } t=0 \text { we have } \varphi_{0}=0, y_{1}=0, \dot{y}_{1}=0, y_{2}=h-\lambda_{0}, \dot{y}_{2}=0 \text {. }
$$

The static deformation of gasket is: $\lambda_{0}=\frac{m_{2} g}{k_{0}}$.

The equations during the separate movement of bodies are:

$$
\begin{aligned}
& \ddot{y}_{1}=\chi g-\omega_{1}^{2} y_{1}-2 \xi_{1} \omega_{1} \dot{y}_{1}+\frac{1}{m_{1}} F(t), \\
& \ddot{y}_{2}=-g-2 \xi_{2} \omega_{2} \dot{y}_{2} .
\end{aligned}
$$

Impact occurs when the mold falls on the gasket. The mold with concrete and the table are moving jointly during impact. The equations of this movement are: 


$$
\begin{aligned}
& \ddot{y}_{1}=g \chi-\omega_{1}^{2} y_{1}-2 \xi_{1} \omega_{1} \dot{y}_{1}+\frac{1}{m_{1}} F(t)+ \\
& +H(z)\left\{2 \xi_{0} \omega_{2} \chi \dot{y}_{1}-\omega_{2}^{2} \chi\left[h-\left(y_{2}-y_{1}\right)\right]-\frac{1}{m_{1}} F_{c o n}\left(y_{1}-y_{2}\right)\right\}, \\
& \ddot{y}_{2}=-g-2 \xi_{2} \omega_{2} \dot{y}_{2}+ \\
& +H(z)\left\{\omega_{2}^{2}\left[h-\left(y_{2}-y_{1}\right)\right]-2 \xi_{0} \omega_{2} \dot{y}_{1}+\frac{1}{m_{2}} F_{c o n}\left(y_{1}-y_{2}\right)\right\} .
\end{aligned}
$$

Here $H(z)$ is Heaviside step function relatively bodies' rapprochement $z=h-\left(y_{2}-y_{1}\right)$.

$$
H(z)=\left\{\begin{array}{ll}
1, & z \geq 0 \\
0, & z<0
\end{array} .\right.
$$

One can see that equations (10) include equations (9). When an impact occurs, $H(z)=1$ and the terms in figure brackets begin to act.

$F_{c o n}\left(y_{1}-y_{2}\right)$ is contact interactive force that simulates an impact and acts only during an impact. The type of this function requires the special consideration. It can be either a linear or non-linear function. Previously, we studied the impact simulation in vibro-impact systems with various impact types $[7,8]$. We'll describe the simulation of soft impact in detail in another paper. We'll compare the simulation by linear forces with different proportionality coefficients and the simulation by nonlinear Hertz' force. Now, when we'll choose the numerical system parameters in Section 4, we'll use the nonlinear Hertz's force $[9,10]$ for calculations.

It is worth to point out that Hertz' contact theory requires that the strains in the contact region be sufficiently small to be within the scope of the linear theory of elasticity. "Metallic solids loaded within their elastic limit inevitably comply with this latter restriction. However, caution must be used in applying the results of the theory to low modulus materials like rubber where it is easy to produce deformations which exceed the restriction to small strains" [11]. For an example we have calculated the impact duration in three cases. We have compared the values obtained by known formula [11,12] and by numerical integration of the motion equations (10). The results are shown in Table 1.

Table 1

\begin{tabular}{|c|c|c|c|}
\hline \multicolumn{2}{|c|}{$\begin{array}{c}\text { Moduli of elasticity of } \\
\text { contacting bodies }\end{array}$} & \multirow{2}{*}{$\begin{array}{c}\text { Impact duration by } \\
\text { formula [11,12], s }\end{array}$} & $\begin{array}{c}\text { Impact duration by } \\
\text { integration of equations } \\
(\mathbf{1 0}), \mathbf{s}\end{array}$ \\
\cline { 1 - 2 } $\boldsymbol{E}_{\mathbf{1}}, \mathrm{N} \cdot \mathrm{m}^{-2}$ & $\boldsymbol{E}_{\mathbf{2}}, \mathrm{N} \cdot \mathrm{m}^{-2}$ & & 0.0135 \\
\hline $3.5 \mathrm{E}+06$ & $2.0 \mathrm{E}+11$ & 0.152 & 0.0125 \\
\hline $3.5 \mathrm{E}+08$ & $2.0 \mathrm{E}+11$ & 0.0256 & 0.00259 \\
\hline $2.0 \mathrm{E}+11$ & $2.0 \mathrm{E}+11$ & 0.00257 & \\
\hline
\end{tabular}


Nevertheless, Hertz's contact theory is widely used to model impact. It provides fairly good and reliable results.

The calculation scheme of shock-and-vibration machine corresponds to twobody 2-DOF vibro-impact system. It is strongly nonlinear non-smooth discontinuous system. It changes its structure during oscillatory motion. The right-hand sides of motion differential equations are discontinuous.

\section{Selection of numerical system parameters}

The basis for the choice of numerical parameters was "Recommendations for vibratory molding of reinforced concrete products" [5]. But, as we wrote in Section 2, this system is very sensitive to changes in its parameters due to strong nonlinearity. The parameters of the exciting force and of the system (the mass of the mold with concrete mixture, the stiffness coefficients of the vibration limiters, etc.) are selected in the machine tuning process. In particular, they are selected in such a way that the operation mode of the machine is close to resonant.

First of all, it is necessary to set damping ratios $\xi_{1}, \xi_{2}, \xi_{0}$. We can assume that the damping ratio should remain in the range $0 \leq \xi \leq 1$ [13].

The damping effect plays a key role when the excitation of oscillations occurs at a frequency close to the natural system frequency. With precise resonance, the amplitude of the oscillations will tend to infinity until damping is taken into account. The actual amplitude in resonance is determined in fact by the magnitude of such damping.

We choose the damping ratios so as to obtain firstly, steady-state $T$-periodic oscillatory process after transient period, and secondly, the amplitude of mold oscillation, close to the required $0.8-1 \mathrm{~mm}$.

Then we select the parameters of stiffness for spring $k_{1}$ and for gasket $k_{0}$. It is known that the parameters of rigidity are relevant ones. They strongly affect the oscillatory process. They also determine the natural system frequency. When selecting these parameters, we are guided by the same principles as when choosing damping coefficients.

Note 1. Elastic moduli of mold and gasket, Poisson's ratios, and gasket radius are included in the expression of contact Hertz's force. The gasket surface is flat. But we consider it as sphere of large radius in order to use the expression for contact Hertz' force.

It must be said that we cannot calculate the natural frequency of the oscillatory system. It changes its structure during movement because the mold comes off the table and then falls down on it. Its oscillatory motion is described by the equations (10). It is seen that Heaviside function $H(z)$ provides a change in structure. Separate motion of bodies and their joint motion during an impact are described by different equations. Therefore, the stiffness matrixes are different for these equations. We'll see a resonance after the formation of amplitude-frequency responses. Then we can clarify some system parameters 
After many numerical experiments, we take the numerical parameters in vibro-impact system as shown in Table 2 .

\begin{tabular}{|l|c|}
\hline Mass of table $m_{1}, \mathrm{~kg}$ & 7400 \\
\hline Mass of mold with concrete $m_{2}, \mathrm{~kg}$ & 15000 \\
\hline Stiffness of rubber gasket $k_{0}, \mathrm{~N} \cdot \mathrm{m}^{-1}$ & $3.0 \cdot 10^{8}$ \\
\hline Stiffness of spring $k_{1}, \mathrm{~N} \cdot \mathrm{m}^{-1}$ & $2.6 \cdot 10^{7}$ \\
\hline Thickness of gasket $h, \mathrm{~m}$ & 0.0275 \\
\hline Damping ratio of dashpot 1 (spring) $\xi_{1}$ & 0.5 \\
\hline Damping ratio of dashpot 0 (gasket) $\xi_{0}$ & 0.02 \\
\hline Damping ratio in concrete mixture $\xi_{2}$ & 0.03 \\
\hline Elastic modulus of mold $E_{2}, \mathrm{~N} \cdot \mathrm{m}^{-2}$ & $2 \cdot 10^{11}$ \\
\hline Elastic modulus of rubber gasket $E_{1}, \mathrm{~N} \cdot \mathrm{m}^{-2}$ & $3 \cdot 10^{7}$ \\
\hline Poisson's ratio of mold $v_{2}$ & 0.3 \\
\hline Poisson's ratio of rubber gasket $v_{1}$ & 0.4 \\
\hline Radius of gasket $R, \mathrm{~m}$ & 10 \\
\hline Amplitude of exciting force $P, \mathrm{~N}$ & $2.44 \cdot 10^{5}$ \\
\hline Frequency of exciting force $\omega, \mathrm{rad} \cdot \mathrm{s}^{-1}$ & 157 \\
\hline
\end{tabular}

Note 2. After integrating the equations of motion (7) and (10), we get a complete picture of the system motion, including the impact time. It should be noted that we were forced to significantly reduce the integration step during an impact. This decrease was much stronger than we did before when we considered a rigid (hard) impact between solids. We think this is due to the great softness of the rubber gasket. Its modulus of elasticity is small; therefore, its deformations during an impact may be not small.

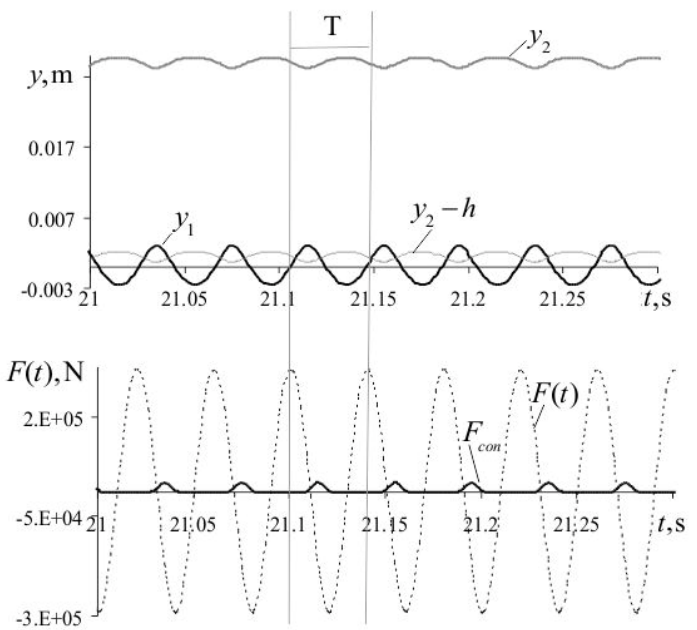

Fig. 3 
We get a graph of contact forces and graphs of all other forces (Fig.5,6) acting in the system during movement. We give the graphs of both bodies' velocities and accelerations.

Time histories and contact force graph (Fig.3) show that the movement is $T$ periodical with one impact per cycle. We can clearly see the great penetration one body into another when we look at the curve $\left(y_{2}-h\right)$. The impact is very soft due the softness and suppleness of the rubber gasket and the penetration is quite large. Amplitude of mold oscillations is $A=0.76 \mathrm{~mm}$.

The phase trajectories (Fig.4) show that $T$-periodical movement is steady-state after passing the transient process.

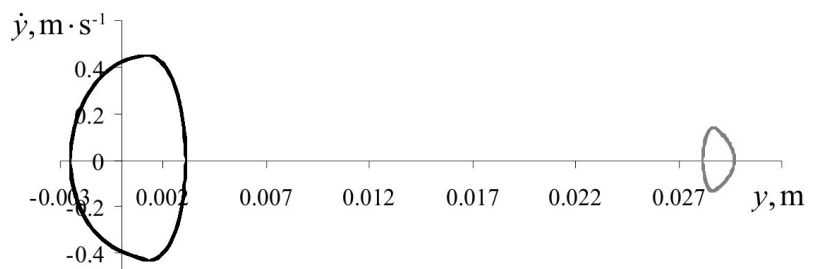

Fig. 4

The speed graph (Fig.5) shows the gradual, not instantaneous reverses in velocities during an impact because the impact is not instantaneous, its duration is long. Impact time $T_{\text {impact }}$ is marked by vertical lines in Fig.5.

And finally, the acceleration graph (Fig. 5) gives the picture of asymmetric accelerations. We have the lower acceleration $w_{L}=39.4 \mathrm{~m} \cdot \mathrm{s}^{-2} \approx 4 \mathrm{~g}$ and the upper acceleration $w_{U}=11.2 \mathrm{~m} \cdot \mathrm{s}^{-2} \approx 1.1 \mathrm{~g}$ ( $\mathrm{g}$ is the gravitational acceleration). Its ratio is $\frac{w_{L}}{w_{U}}=3.6$.

\section{Conclusions}

The created mathematical model of platform-vibrator with shock corresponds to the two-body 2-DOF vibro-impact system. It is strongly nonlinear nonsmooth discontinuous system. It has some peculiar properties, namely: the upper body with very large mass breaks away from the lower body during vibrational motion; both bodies move separately; the upper body falls down onto the constraint that is on the rubber gasket; the impact that occurs is soft one due to the softness and flexibility of the rubber gasket. The numerical parameters for this system were chosen in such a way that: firstly, they provide the fulfillment of requirements for real machine, and secondly, they allow analyzing its dynamic behavior by nonlinear dynamics tools. The created model provides: $T$ periodic steady-state movement after passing the transient process; the appropriate value of mold oscillations amplitude $A=0.76 \mathrm{~mm}$; the satisfactory 
value of the asymmetry coefficient - the ratio of lower acceleration to the upper acceleration is $\frac{w_{L}}{w_{U}}=3.6$.

Thus, we believe that the created model meets all the necessary requirements.

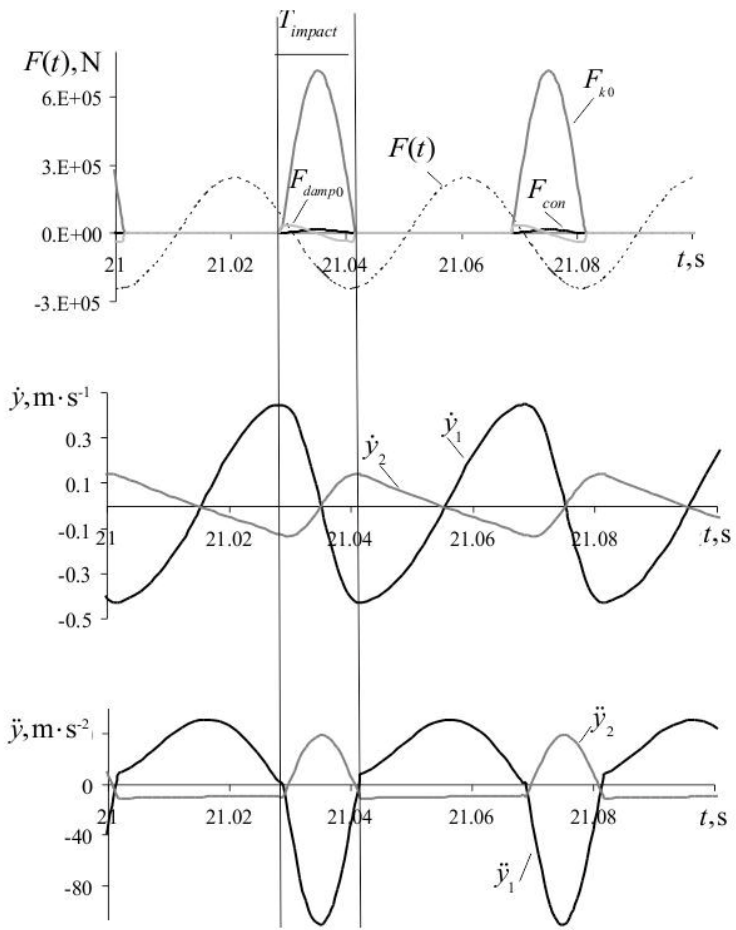

Fig. 5

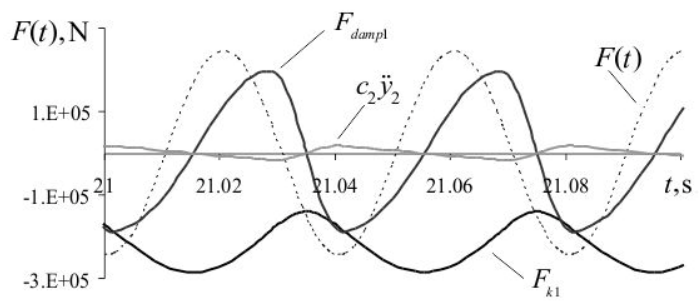

Fig. 6 


\section{REFERENCES}

1. Nazarenko I. I. (2010). Applied problems of the vibration systems theory: Textbook (2nd edition) // Kyiv .: Publishing House "Word". - 2010. (in Ukranian)

2. Gusev, B. V., \& Zazimko, V. G. (1991). Vibration Technology of Concrete. Budivelnik, Kiev. (in Russian)

3. Gusev, B. V., Deminov, A. D., \& Kryukov, B. I. Impact-Vibrational Technology of Compaction of Concrete Mixtures.Stroiizdat, Moscow. - 1982. (in Russian)

4. Borschevsky A.A., Ilyin A.S. The Mechanical equipment for manufacture of building materials and products. The textbook for high schools on Pr-in builds. Publishing house the Alliance, 2009. - 368 p.(in Russian)

5. Recommendations on vibration forming of reinforced concrete products. M., 1986. (in Russian)

6. Bazhenov V. A., Dehtyaryuk E. S. (1998). Construction mechanics. Dynamics of structures. Educ. manual. K .: IZMN. (in Ukranian)

7. Bazhenov, V., Pogorelova, O., Postnikova, T., \& Goncharenko, S. (2009). Comparative analysis of modeling methods for studying contact interaction in vibroimpact systems. Strength of materials, 41(4).

8. Bazhenov, V. A., Pogorelova, O. S., \& Postnikova, T. G. (2013). Comparison of two impact simulation methods used for nonlinear vibroimpact systems with rigid and soft impacts. Journal of Nonlinear Dynamics, 2013.

9. Bazhenov V. A., Pogorelova O. S., Postnikova T. G. (2017). Stability and Discontinious Bifurcations in Vibroimpact System: Numerical investigations. LAP LAMBERT Academic Publ. GmbH and Co. KG Dudweiler, Germany.

10. Bazhenov V.A., Pogorelova O. S., Postnikova T. G. (2019). Intermittent and Quasiperiodic Routes to Chaos in Vibroimpact System. Numerical simulation. LAP LAMBERT Academic Publishing, Beau Bassin, Mauritius, 2019.

11. Johnson, K. L. (1974), Contact Mechanics, 1985, Cambridge University Press, Cambridge.

12. Goldsmith, W. (1960). Impact, the theory and physical behaviour of colliding spheres. Edward Arnold (Publishers) Ltd, 339.

13. Sönnerlind, H. Damping in Structural Dynamics: Theory and Sources. COMSOL Blog. https://www.comsol.com/blogs/damping-in-structural-dynamics-theory-and-sources/

Стаття надійшла 28.01.2020

Баженов В.А., Погорелова О.С., Постнікова Т.Г.

\section{СТВОРЕННЯ МАТЕМАТИЧНОЇ МОДЕЛІ УДАРНО-ВІБРАЦІЙНОГО МАЙДАНЧИКА ДЛЯ УЩІЛЬНЕННЯ ТА ФОРМУВАННЯ БЕТОННИХ ВИРОБІВ}

Вібраційні майданчики $є$ головним обладнанням при виробництві бетонних та залізобетонних виробів. Ударно-вібраційна технологія при виробництві збірного залізобетону на низькочастотних резонансних вібро-майданчиках значно поліпшує якість виробів та ступінь їхньої заводської готовності. Ця технологія використовується для виробництва великогабаритних виробів.

В статті описується створення математичної моделі ударно-вібраційного майданчика, де реалізується режим асиметричних коливань, у якому верхнє та нижнє прискорення форми 3 бетоном мають різні значення. Створена математична модель відповідає двох-масовій віброударній системі 3 двома ступнями вільності. Це сильно нелінійна негладка розривна система, яка має такі особливості: верхнє тіло дуже великої маси відривається під час коливального руху від нижнього тіла, і тоді тіла рухаються окремо; потім верхнє тіло падає на м'який обмежник; відбувається м'який удар. Моделювання м'якого удару потребує окремого обговорення. У цій статті удар моделюється нелінійною контактною силою відповідно до квазістатичного контактного закону Герца.

Числові параметри системи вибиралися таким чином, щоб по-перше, вони забезпечували виконання вимог до реальної машини, та по-друге, дозволили виконати аналіз її динамічної поведінки засобами нелінійної динаміки. Створена модель достатньо добре забезпечує 
виконання низки вимог, а саме: $T$-періодичний усталений рух після перехідного процесу; придатне значення амплітуди коливань форми; задовільну величину коефіцієнту асиметрії, а саме відношення нижнього прискорення до верхнього.

Ключові слова: ударно-вібраційний майданчик, вібро-ударна система, форма з бетоном, верхнє та нижнє прискорення.

\section{UDC 539.3}

Bazhenov V.A., Pogorelova O.S., Postnikova T.G. Creation of mathematical model of platformvibrator with shock, designed for concrete products compaction and molding Lyapunov exponents estimation for strongly nonlinear nonsmooth discontinuous vibroimpact system // Strength of Materials and Theory of Structures: Scientific-and-technical collected articles. - K.: KNUBA, 2020. - Issue 104. - P. 103-116.

Platform-vibrators are the main molding equipment in the production of precast concrete elements. Shock-vibration technology for the precast concrete production on low-frequency resonant platform-vibrators significantly improves the quality of the products front surfaces and the degree of their factory readiness. This technology is used to produce large elements.

We describe the creation of a mathematical model for platform-vibrator that uses shock to produce asymmetric oscillations. The values of the upper and lower accelerations of the mold with concrete have different values with shock-vibration technology.

The created mathematical model corresponds to the two-body 2-DOF vibro-impact system. It is strongly nonlinear non-smooth discontinuous system. It has some peculiar properties, namely: the upper body with very large mass breaks away from the lower body during vibrational motion; both bodies move separately; the upper body falls down onto the soft constraint; the impact that occurs is soft one due to the softness and flexibility of the constraint. The soft impact simulation requires special discussion. In this paper, we simulate a soft impact by a nonlinear contact force in accordance with the Hertz quasistatic contact law.

The numerical parameters for this system were chosen in such a way that: firstly they provide the fulfillment of requirements for real machine, and secondly they allow analyzing its dynamic behavior by nonlinear dynamics tools. The created model is well enough to fulfill a number of requirements, namely: T-periodic steady-state movement after passing the transient process; the appropriate value of mold oscillations amplitude; the satisfactory value of the asymmetry coefficient that is the ratio of lower acceleration to the upper acceleration. We believe that the created model meets all the necessary requirements.

Table 2. Fig. 6. Ref. 13

\section{УДК 539.3}

Баженов В.А., Погорелова О.С., Постнікова Т.Г. Створення математичної моделі ударновібраційного майданчика для ущільнення та формування бетонних виробів // Опір матеріалів і теорія споруд: наук.-тех. збірн. - К.: КНУБА, 2020. - Вип. 104. - С. 103-116. Англ.

Вібраційні майданчики $\epsilon$ головним обладнанням при виробництві бетонних та залізобетонних виробів. Ударно-вібраційна технологія при виробництві збірного залізобетону на низькочастотних резонансних вібро-майданчиках значно поліпиує якість виробів та ступінь їхньої заводської готовності. Ця технологія використовується для виробництва великогабаритних виробів.

В статті описується створення математичної моделі ударно-вібраційного майданчика, де реалізується режси асиметричних коливань, у якому верхнє та нижнс прискорення форми з бетоном мають різні значення. Створена математична модель відповідає двох-масовій вібро-ударній системі з двома ступнями вільності. Це сильно нелінійна негладка розривна система, яка має такі особливості: верхнє тіло дуже великої маси відривається під час коливального руху від нижнього тіла, i тоді тіла рухаються окремо; потім верхне тіло падає на м'який обмежник; відбувається м'який удар. Моделювання м'якого удару потребує окремого обговорення. У иій статті удар моделюється нелінійною контактною силою відповідно до квазістатичного контактного закону Герца. 
Числові параметри системи вибиралися таким чином, щуоб по-перше, вони забезпечували виконання вимог до реальної машини, та по-друге, дозволили виконати аналіз ї̈ динамічної поведінки засобами нелінійної динаміки. Створена модель достатньо добре забезпечує виконання низки вимог, а саме: T-періодичний усталений рух після перехідного процесу; придатне значення амплітуди коливаньформи; задовільну величину коефіцієнту асиметрії, а саме відношення нижнього прискорення до верхнього.

Табл 2. Рис. 6. Бібліогр. 13.

Автор (вчена ступень, вчене звання, посада): доктор технічних наук, професор, академік Національної академії педагогічних наук України, директор НДІ будівельної механіки БАЖЕНОВ Віктор Андрійович

Адреса робоча: 03680 Украӥна, м. Київ, Повітрофлотський проспект 31, Київський національний університет будівництва і архітектури.

Робочий тел.: +38(044) 245-48-29.

мобільний тел.: +38(067)111-22-33

Імейл: bazhenov.va@knuba.edu.ua

ORCID ID: https//orcid/org/0000-0002-5802-9848

Автор (вчена ступень, вчене звання, посада): кандидат фізико-математичних наук, стариий науковий співробітник, провідний науковий співробітник НДІ будівельної механіки ПОГОРЕЛОВА Ольга Семенівна

Адреса робоча: 03680 Украӥна, м. Київ, Повітрофлотський проспект 31, Київський наиіональний університет будівництва і архітектури, ПОГОРЕЛОВІЙ Ользі Семенівні.

Робочий тел.: +38(044) 245-48-29

Мобільний тел.: +38(067) 606-03-00

Імейл: pogos13@ukr.net

ORCID ID: http://orcid.org/0000-0002-5522-3995

Автор (вчена ступень, вчене звання, посада): кандидат технічних наук, стариий науковий співробітник, старший науковий співробітник НДІ будівельної механіки ПОСТНІКОВА Тетяна Георгївна

Адреса робоча: 03680 Украӥна, м. Київ, Повітрофлотський проспект 31, Київський національний університет будівництва і архітектури, ПОСТНІКОВІЙ Тетяні Георгївні.

Робочий тел.: +38(044) 245-48-29

Мобільний тел.: $+38(050)$ 353-47-19

Імейл: postnikova.tg $a$ knuba.edu.ua

ORCID ID: http://orcid.org/0000-0002-6677-4127 